\title{
Study on Recognition of Metallic Ions by a Photo-Sensitivity Liquid Crystal of Ethylcyclohexyl Acyloxy Azobenzoic Acid
}

\author{
Yongsheng Wei ${ }^{*}$ and Minyan Zheng \\ School of Chemistry and Chemical Engineering, Xianyang Normal University, \\ Shaanxi, Xianyang 712000, China \\ *Corresponding author
}

\begin{abstract}
A ethyl cyclohexanyloxy azobenzoic acid molecule constructed by liquid crystalline structure was synthesized as a sample in this paper. The compound was a multi-functional molecule with liquid crystalline and photo-sensitive properties. The recognition of some divalent metallic ions such as $\mathrm{Fe}^{2+}, \mathrm{Mn}^{2+}$, $\mathrm{Ba}^{2+}, \mathrm{Pb}^{2+}, \mathrm{Cu}^{2+}$ by this compounds were researched by $\mathrm{UV}$ spectrometry. The mole ratio of 1 to 3 in a solvent of methanol were better condition to conduct this process. The result showed the azo liquid crystal molecule can recognize common divalent ions $\left(\mathrm{Fe}^{2+}, \mathrm{Mn}^{2+}, \mathrm{Ba}^{2+}, \mathrm{Pb}^{2+}, \mathrm{Cu}^{2+}\right)$. A strong recognition was exhibited between the azo liquid crystal molecules and $\mathrm{Cu}^{2+}$ ion.
\end{abstract} ions

Keywords-liquid crystal; photographic materials; azo; metallic

\section{INTRODUCTION}

Azo group $(\mathrm{N}=\mathrm{N})$ in compounds has unique optical properties, because the trans-cis isomerization of the group[1]. Trans azo structure was existed in a low energy state, while it transforms to cis structure under expose to UV-light. The cis structure can recover to trans one under sun-light. So the molecules are called bistable molecule [2]. Azo compounds are mainly used as dyes [3-5]. Because its unique properties, it often applied widely as light responsive materials [6], optical information storage[7]. The liquid crystalline material has special physical, chemical and optical properties. Azo group is functional group of special optical activity [8-10]. If the liquid crystal compounds are combined with the optically active group of azo form. The new molecules play both roles of liquid crystal display and optical information storage [11].

In this paper, an azo compound with structure of liquid crystalline core and azo group named ethyl cyclohexyl acyloxy benzoic acid was used as a basic sample. Because of the carboxyl functional groups at the end of the compound, it may has the interaction with metal ions and this effect will be observed by UV spectrometer so that its selectivity to metallic ions can be found. Some divalent metal ions such as $\mathrm{Fe}^{2+}, \mathrm{Ba}^{2+}$, $\mathrm{Mn}^{2+}$, and $\mathrm{Cu}^{2+}$ and $\mathrm{Pb}^{2+}$ ion were used as determiands.

\section{EXPERIMENTAL SECTION}

\section{A. Materials}

All initial intermediate used in the synthesis were prepared in our laboratory with purity higher than 99\%, and characterized by IR, GC-MS and 1H NMR methods. Other reagents from commercial sources and used without further purification. Manganese sulfate, barium nitrate, copper sulfate, lead nitrate and ferrous sulfate (pure) and the domestic methanol (HPLC grade) analysis were from the domestic market.

\section{B. Instruments and Conditions}

The purities of compounds were detected by LC-10A (Shimadzu) instrument with methanolas eluent and flowing rate was $1 \mathrm{~mL} / \mathrm{min}$. Elemental analyses were conducted by PE-2400 analyzer (Perkin Elmer). UV spectra were determined by Agilent 8453 Spectrometer (Agilent Technologies). IR (KBr) spectra were recorded on a Vertex 70 spectrophotometer (Bruker). The irradiation of samples was carried out by hand-held UV lamp ZF-7A(Shanghai Jiapeng Technology Co. Ltd.). Mass data were recorded on a GCMS-QP2010 (Shimadzu) and IE was $70 \mathrm{ev} .{ }^{1} \mathrm{H}$ NMR spectra were obtained on a Bruker Avance 500 spectrometer $(500 \mathrm{MHz}$, solvent $\mathrm{CDCl}_{3}$.

\section{EXPERIMENTAL PROCESS}

\section{Synthesis of the Sample}

The azo compound of ethyl cyclohexyloxy azobenzoic acid was prepared using the method reported elsewhere and the spectral values were in accordance with the assigned structure[12]. Its structure was shown as followed.

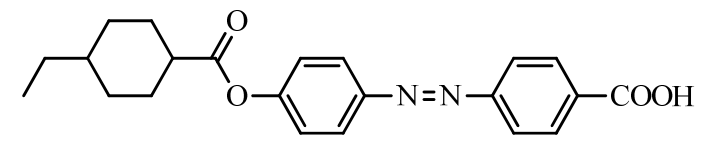

\section{Preparation of Sample Solution}

$0.0190 \mathrm{~g}$ of Ethyl cyclohexanyloxy azobenzoic acid were dissolved in THF and fixed volume to $50 \mathrm{~mL}$. The concentration was $0.00100 \mathrm{~mol} \cdot \mathrm{L}^{-1}$.

\section{E. Hoice of Solvent}

Sample solution (prepared above) of $0.3 \mathrm{~mL}, 0.5 \mathrm{~mL}$ and 1 $\mathrm{mL}$ were drawn in the comparison tube with methanol, THF, 
$\mathrm{CH}_{2} \mathrm{Cl}_{2}$ and cyclohexane as solvent, respectively, and then fixed volume to $10 \mathrm{~mL}$. The absorbance of $0.3 \mathrm{~mL}$ of methanol solution at $330 \mathrm{~nm}$ was 1.4479 with peak of better shape. In addition, no any interaction between methanol and metal ions was found in the solution, so the methanol was taken as solvent in the following process.

TABLE I. THE MAXIMUM ABSORBANCE (A) OF THE TARGET MOLECULE IN DIFFERENT SOLVENTS

\begin{tabular}{ccccc}
\hline Solvent & methanol & $\begin{array}{c}\text { cyclohexa } \\
\text { ne }\end{array}$ & THF & $\begin{array}{c}\text { dichorometha } \\
\text { ne }\end{array}$ \\
\hline$\lambda(\mathrm{nm})$ & 330 & 330 & 333 & 332 \\
Absorbance & 1.4479 & 1.3437 & 0.8772 & 1.2585 \\
\hline
\end{tabular}

\section{A. Preparation of Metallic Ions}

These metal ions were preparation in solvent of super ultrapure water with their concentration as Table 2 .

TABLE II.THE CONCENTRATIONS OF DETERRMINAND OF METAL IONS $\left(\mathrm{MMOL} \cdot \mathrm{ML}^{-1}\right)$

\begin{tabular}{cccccc}
\hline Metal ions & $\begin{array}{c}\mathrm{FeSO}_{4} .7 \\
\mathrm{H}_{2} \mathrm{O}\end{array}$ & $\begin{array}{c}\mathrm{MnSO}_{4} \cdot \mathrm{H}_{2} \\
\mathrm{O}\end{array}$ & $\mathrm{CuSO}_{4}$ & $\begin{array}{c}\mathrm{Ba}(\mathrm{NO} \\
3)_{2}\end{array}$ & $\begin{array}{c}\mathrm{Pb}(\mathrm{NO} \\
3)_{2}\end{array}$ \\
\hline $\begin{array}{c}\text { Molecular } \\
\text { weight }\end{array}$ & 278 & 169.02 & 249.68 & 261.34 & 331.23 \\
& & & & & \\
Concentration & $\begin{array}{c}0.00100 \\
4\end{array}$ & 0.000994 & $\begin{array}{c}0.00099 \\
9\end{array}$ & $\begin{array}{c}0.0010 \\
03\end{array}$ & $\begin{array}{c}0.0010 \\
14\end{array}$ \\
\hline
\end{tabular}

\section{Results AND Discussion}

\section{A. Trans-Cis Isomerization of Sample in Methanol and THF.}

The trans-cis isomerization of sample in methanol (Fig. 1A) or in THF (Fig. 1B) under irradiation of UV light of $360 \mathrm{~nm}$. The change of curves was observed in these UV spectra. The peak at $330 \mathrm{~nm}$ was dropped gradually, while the other peak at $430 \mathrm{~nm}$ was increased with time. The state was reached within $70 \mathrm{~min}$. The trans-cis isomerization of sample in tetrahydrofuran also need $70 \mathrm{~min}$. But the shape of peak was not as good as in method solution.

\section{B. The Molar Ratio of the Sample to Metallic Ions.}

The mixture solution were prepared with the molar ratios of $1: 1,1: 2,1: 3$ (the sample to metallic ions) and fixed volume to $10 \mathrm{~mL}$. The result showed that a higher interaction was observed with the molar ratio of 1 to 3 .

\section{The Time of Interaction}

The sample of $0.5 \mathrm{~mL}$ mixed with a metal ion of $1.5 \mathrm{~mL}$, and then fixed the volume to $10 \mathrm{~mL}$ After 5, 10, 15 and $20 \mathrm{~min}$, its absorbance were determined. The result showed that the absorbance were unchanged after $10 \mathrm{~min}$. So $10 \mathrm{~min}$ were taken as reaction time to research the interaction between the azo sample and metal ions.

\section{The Interaction Between Azo Sample and Metallic Ions}

The interactions between azo sample and metal ions were studied under conditions shown above. The process was: azo sample of $0.5 \mathrm{~mL}$ and a metal ion of $1.5 \mathrm{~mL}$ were taken into a comparison tube, and then the volume was fixed to $10 \mathrm{~mL}$ with the solvent of methanol. The UV spectra were then obtained in a cuvette. Then solution in the cuvette was under irradiation of UV light of $360 \mathrm{~nm}$ for $10 \mathrm{~min}$, the UV spectrum was determined again. Repeated the step above, until the peak of $330 \mathrm{~nm}$ was unchanged.

The UV spectra of every metal ion were obtain by only taking the metal ion of $1.5 \mathrm{~mL}$ into another comparison tube and repeated all steps above. The result showed the spectra of every metal ion measured has little absorption in UV reign.

The interaction between azo sample and $\mathrm{Fe}^{2+}$ were shown as Fig. 2A and the UV spectrum of $\mathrm{Fe}^{2+}$ were as Fig. 2B shown. The results also showed that some divalent ions such as $\mathrm{Ba}^{2+}$ and $\mathrm{Cu}^{2+}$ has interaction with the azo sample.(as Fig. 3 shown). The absorbance of every ion were listed in Table 3 .
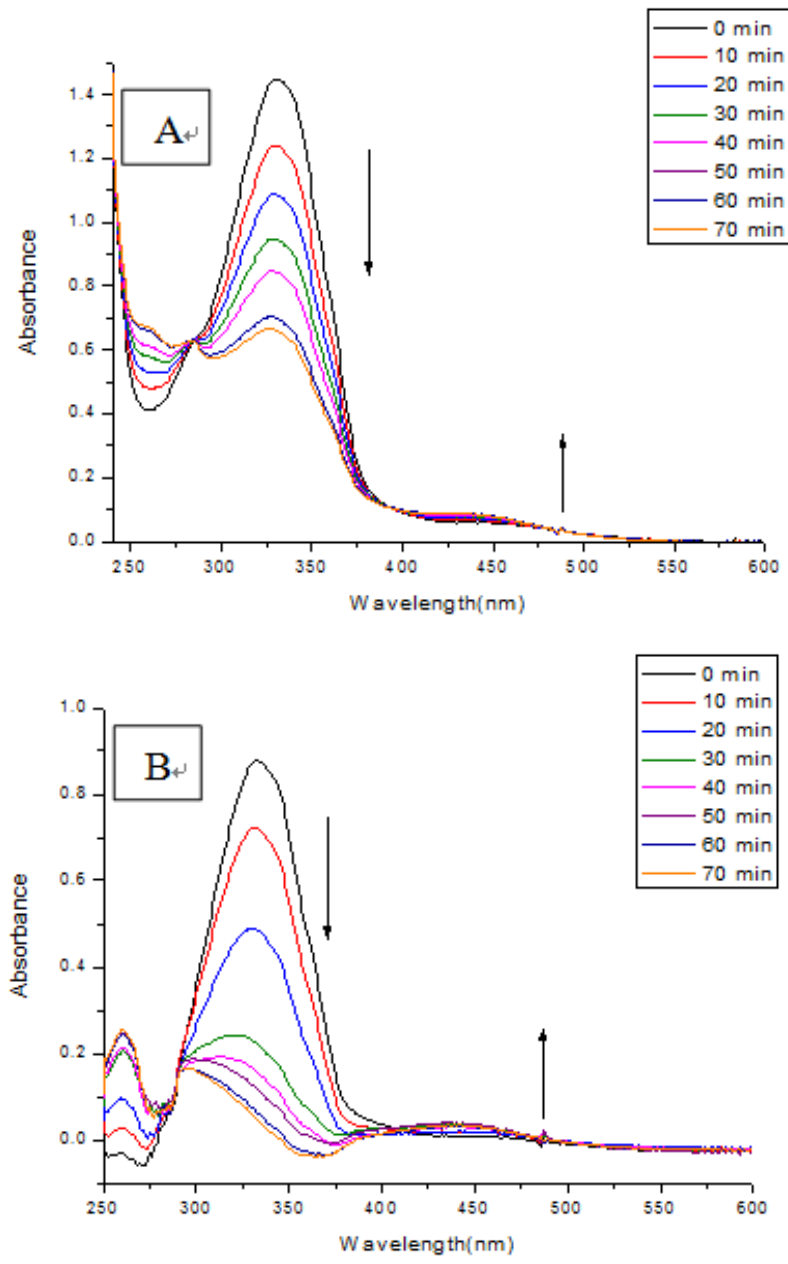

FIGURE I. THE UV SPECTRA OF TARGET COMPOUND IN METHANOL(A) OR THF(B) UNDER DIFFERENT EXPOSURE TIME OF UV-LIGHT 

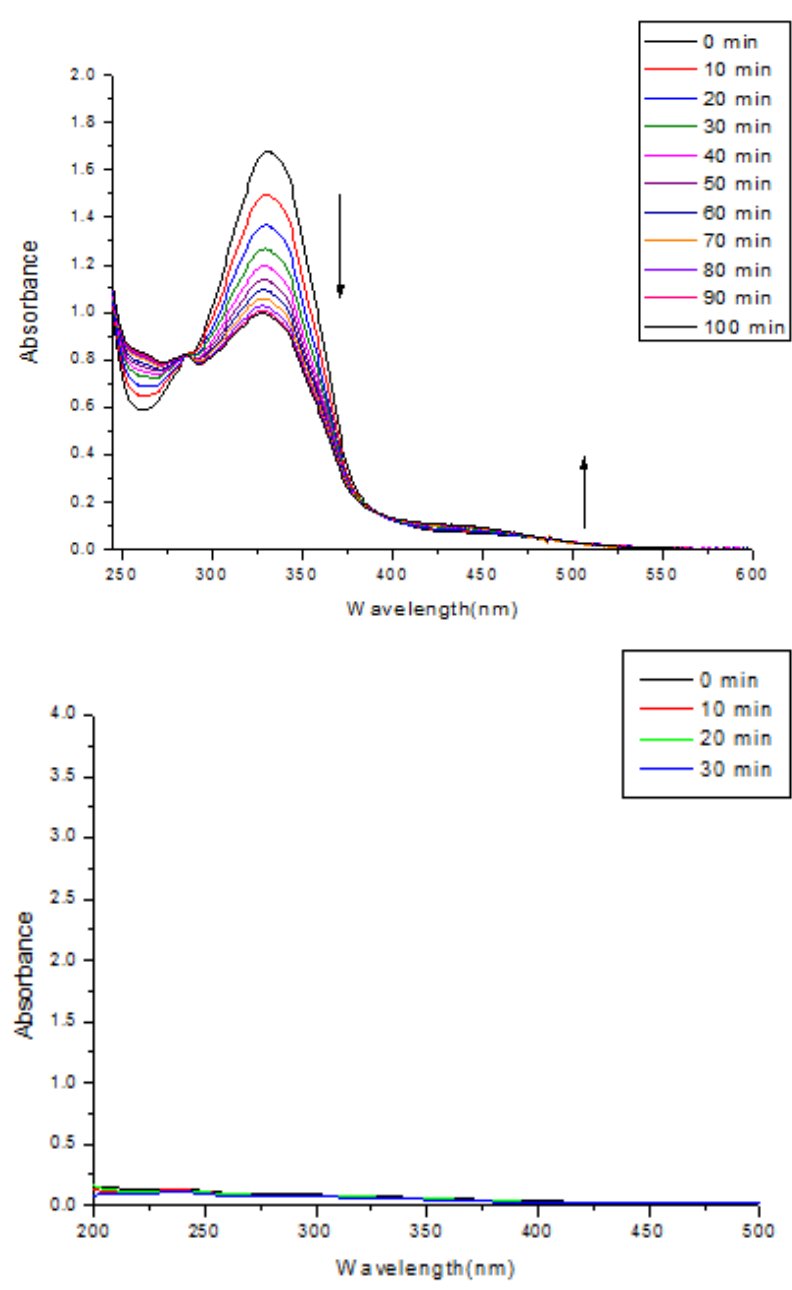

FIGURE II. THE UV SPECTRUM DURING THE PHOTO-ISOMERIZATION BETWEEN THE COMPOUND AND FE ${ }^{2+}(\mathrm{A})$ AND THE SPECTRUM OF $\mathrm{FE}^{2+}$ UNDER THE SAME CONDITION WITH A (B)

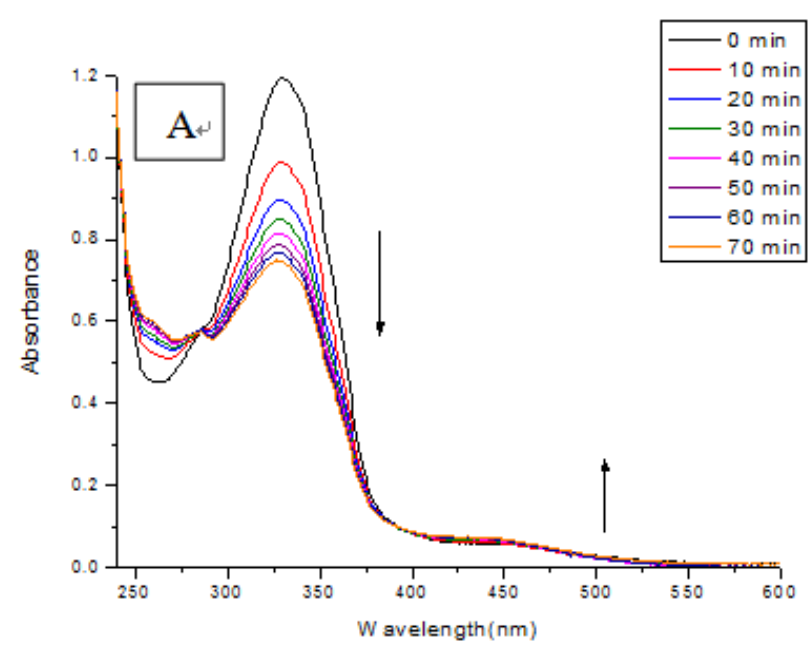

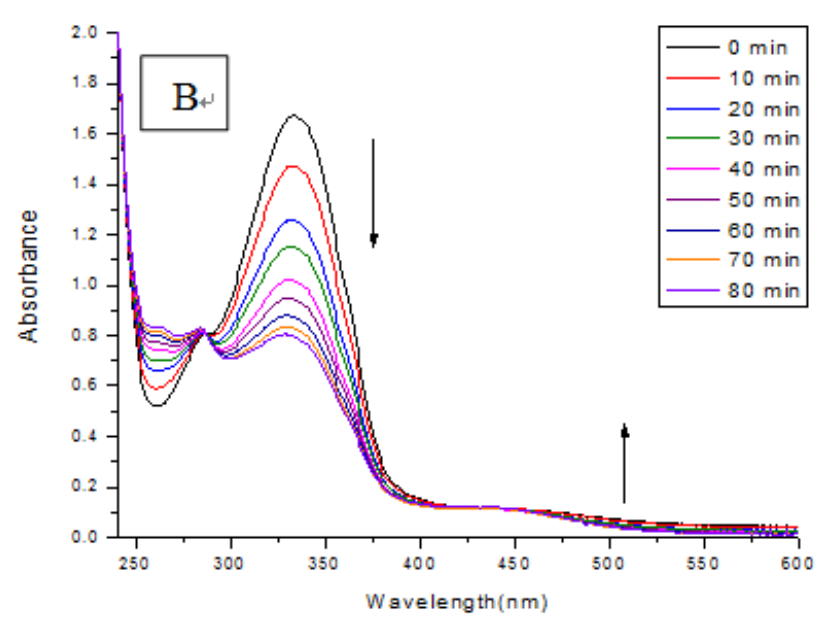

FIGURE III. THE UV SPECTRA OF INTERACTION BETWEEN AZO SAMPLE AND CU ${ }^{2+}(\mathrm{A}), \mathrm{BA}^{2+}(\mathrm{B})$, RESPECTIVELY.

TABLE III. THE ABSORBANCE OF EVERY MIXTURE SOLUTION BEFORE AND AFTER IRRADIATION OF UV-LIGHT

\begin{tabular}{|c|c|c|c|c|c|c|}
\hline \multirow{2}{*}{$\begin{array}{c}\text { Irradiatio } \\
n \\
\text { time } /(\min \\
)\end{array}$} & \multicolumn{6}{|c|}{ A } \\
\hline & $\begin{array}{c}\text { methan } \\
\text { ol }\end{array}$ & $\mathrm{Fe}^{2+}$ & $\mathrm{Ba}^{2+}$ & $\mathrm{Mn}^{2+}$ & $\mathrm{Cu}^{2+}$ & $\mathrm{Pb}^{2+}$ \\
\hline \multirow[t]{2}{*}{0} & 1.4479 & 1.677 & 1.671 & 1.507 & 1.192 & 1.34737 \\
\hline & 3 & 04 & 25 & 94 & 48 & \\
\hline \multirow[t]{2}{*}{10} & 1.2389 & 1.494 & 1.472 & 1.322 & 0.986 & 1.14321 \\
\hline & 9 & 25 & 85 & 04 & 84 & \\
\hline \multirow[t]{2}{*}{20} & 1.0866 & 1.366 & 1.255 & 1.136 & 0.895 & 0.99441 \\
\hline & 2 & 96 & 96 & 34 & 73 & \\
\hline \multirow[t]{2}{*}{30} & 0.9466 & 1.264 & 1.151 & 1.018 & 0.847 & 0.83631 \\
\hline & & 86 & 61 & 78 & 7 & \\
\hline \multirow[t]{2}{*}{40} & 0.8444 & 1.192 & 1.018 & 0.932 & 0.812 & 0.79973 \\
\hline & 6 & 2 & 19 & 01 & 16 & \\
\hline \multirow[t]{2}{*}{50} & 0.6997 & 1.135 & 0.945 & 0.853 & 0.784 & 0.7265 \\
\hline & 7 & 2 & 23 & 86 & 39 & \\
\hline \multirow[t]{2}{*}{60} & 0.6997 & 1.091 & 0.875 & 0.788 & 0.764 & 0.68554 \\
\hline & 7 & 1 & 85 & 85 & 64 & \\
\hline \multirow[t]{2}{*}{70} & 0.6620 & 1.054 & 0.829 & 0.764 & 0.744 & - \\
\hline & 1 & 67 & 46 & 23 & 69 & \\
\hline \multirow[t]{2}{*}{80} & & 1.023 & 0.797 & 0.737 & 0.736 & - \\
\hline & & 1 & 23 & 06 & 82 & \\
\hline \multirow[t]{2}{*}{90} & - & 1.001 & - & 0.716 & - & - \\
\hline & & 75 & & 18 & & \\
\hline \multirow[t]{2}{*}{100} & - & 0.991 & - & 0.690 & - & - \\
\hline & & 06 & & 61 & & \\
\hline
\end{tabular}

The result showed that an interaction can be found between the azo sample and metal ions such as $\mathrm{Fe}^{2+}, \mathrm{Ba}^{2+}, \mathrm{Mn}^{2+}, \mathrm{Cu}^{2+}$ and $\mathrm{Pb}^{2+}$. These metallic ions has little absorbance in UV reign. The maximum absorbance of the sample in methanol was 1.44793 . The maximum absorbance between the azo sample and some divalent metal ions such as $\mathrm{Fe}^{2+}, \mathrm{Ba}^{2+}, \mathrm{Mn}^{2+}, \mathrm{Cu}^{2+}$ and $\mathrm{Pb}^{2+}$ were $1.67704,1.67125,1.50794,1.19248$ and 1.34737 , respectively. Among them, the absorbance of the sample with $\mathrm{Fe}^{2+}, \mathrm{Ba}^{2+}$ or $\mathrm{Mn}^{2+}$ were more than 1.44793 , while the absorbance of the sample with $\mathrm{Cu}^{2+}$ or $\mathrm{Pb}^{2+}$ were lower than 1.44793 , indicating a strong interaction between the sample and $\mathrm{Cu}^{2+}$ or $\mathrm{Pb}^{2+}$ were seen from these values. When the sample interacted with $\mathrm{Pb}^{2+}$, 
the trans-cis isomeration can be fulfilled within $60 \mathrm{~min}$ (less than $80 \mathrm{~min}$ ), indicating a stronger interaction between the azo sample and $\mathrm{Pb}^{2+}$ ion. Although the mechanism of interaction between the compound and metallic ions was not clear, the cis structure also can transform to trans one by radiation of Sun-light, suggesting that these divalent metal ions can not destroy the structure of azo groups. The azo compound in this paper has the potential to recognize some divalent ions, especially $\mathrm{Cu}^{2+}$ and $\mathrm{Pb}^{2+}$.

\section{ACKNOWLEDGEMENTS}

We gratefully acknowledge the financial support from the National Natural Science Foundation of China (No. 21102121); The Natural Science Foundation of Shaanxi Province (No. 2014JM2-2014).

\section{REFERENCES}

[1] V. S. Mikulich, Al. A. Muravsky, An. A. Murauski, V. E. Agabekov. Effect of cis/trans- isomerisation on photoalignment of azo dyes. Russian Journal of General Chemistry, 85(2015), 571-576

[2] T. Sun, Y. Li, F. Xin , S. Li, Y. Hou, A. Hao. A photo-switched supramolecular system based on cyclodextrins and azo compounds. Progress in Chemistry, 24(2012), 71-76

[3] T. Wan, H. Xu, Y. Yuan, W. He. Preparation and photochemical behavior of a cationic azobenzene dye-montmorillonite intercalation compound Journal of Wuhan University of Technology-Mater. 22(2007), 466-469

[4] N. A. Davidenko, I. I. Davidenko, I. A. Savchenko, S. L. Studzinsky. Electro-optical properties of film polymer composites with bis-azo dyes and bis-azo metal complexes, Journal of Applied Spectroscopy, 79(2012), 490-494

[5] D. Cui, G. Li, D. Zhao, M. Zhao. Effect of quinoid redox mdiators on the aerobic decolorization of azo dyes by cells and cell extracts from Escherichia coli. Environmental science and pollution research international, 22(2015), 4621-4630

[6] W. Qin, Z. Li, J. Li, L. Zhang, R. Liu, H. Liu. Synthesis and characterization of azobenzene hydroxypropyl cellulose with photochromic and thermotropic liquid crystal properties. Cellulose. 22(2015), 203-214

[7] I. A. Budagovsky, A. S. Zolot'ko, V. N. Ochkin, M. P. Smayev, S. A. Shvetsov, A. Yu. Bobrovsky, N. I. Boiko, V. P. Shibaev, M. I. Barnik, Orientational optical nonlinearity of nematic liquid crystals induced by high-molecular-mass azo-containing compounds, Polymer Science Series A, 53(2011), 655

[8] J. Li, X. Zhang, J. Gooch, W. Sun, H. Wang, K. Wang. Photo- and $\mathrm{pH}$-sensitive azo-containing cationic waterborne polyurethane, Polymer Bulletin, 72(2015), 881-895

[9] A. M. Resmerita, N. Hurduc, D. Adès, A. Siove, Surface properties, thermal behavior, and molecular simulations of azo-polysiloxanes under light stimuli. Insight into the relaxation, Macromolecular Research, 18(2010), 721-729

[10] J. Bi, Y. Liu, S. Liang, W. Wu, R. Yuan, L. Wu. Novel hierarchical architectures of Sb2WO6: template-free hydrothermal synthesis and photo catalytic reduction property for azo compound, Journal of Nanoparticle Research, 15(2013), 1661

[11] J. Liu, Q. Zhang , J. Zhang. Photochromism of the Star-like Liquid Crystals Containing Azobenzene, Chinese Journal of Chemical Physics, 18(2005), 817-820

[12] M. Zheng, Y. Wei, W. Geng, Synthesis,Photo-sensitive and electrochemical properties of Asymmetric liquid crystals based on Tri-ring Azo-Benzoic acid. Chemical Journal of Chinese Universities, 36(2015), 899-906 